\title{
DESCRIPTION OF PHYSICAL ACTIVITY AND NUTRITIONAL STATUS OF STUDENTS IN PRIMARY SCHOOL COUNTRY BENDUNGAN KEC. PABELAN KAB. SEMARANG
}

\author{
*Cahyo Wibowo, Venti Agustina, Tri Ari Kusnanto \\ Correspondence: Universitas Kristen Satya Wacana, Salatiga, Indonesia \\ E-mail: cahyo.wibowo@uksw.edu
}

\begin{abstract}
Physical activity is a movement that is obtained from the work of the skeletal muscles which require energy. Physical activity requires energy, depending on the intensity and work of the muscles. Nutritional status is a health condition that is built by nutrient intakes. The method in this research is descriptive quantitative research. The research respondents consisted of 52 students of class IV-VI. Physical activity data techniques used the PAQ-C (Physical Activity Questionnaire for Children) questionnaire and nutritional status used anthropometric measurements with body weight and height measurements, calculated using the BMI (Body Mass Index) formula. The results showed that most of the students at SDN Bendungan Kec. Pabelan Kab. Semarang. The results of the most physical activity were in the moderate category as many as 25 students with a proportion (48\%) of 52 students, and while for the most nutritional status in the normal category, there were 29 students with a proportion (55.7\%).
\end{abstract}

\section{Keywords: Students, Physical Activity, Nutritional Status}

\section{Introduction}

Physical activity is a movement that is obtained from the work of the skeletal muscles which require energy. Every activity doing physical activity requires energy depending on the length of the intensity and muscle work. Physical activity needs to be done because it is to maintain health, especially mental and physical health, to stay healthy and fit (Kemenkes RI, 2017). Physical activity is important for students to carry out daily activities (Rubiyatno, 2014). Physical activity is divided into two levels, namely light and heavy physical activity (Danari, 2013). Light activities are body movements such as daily activities such as walking and household chores. Strenuous physical activity requires a lot of energy, for example lifting weights, climbing mountains, and swimming.

Factors related to physical activity are nutritional status, which is the state of the body due to health conditions that are influenced by nutrient intakes (Sofingi,

PJKR

https://jurnal.unimed.ac.id/2012/index.php/jpehr 
2018). The nutritional needs of elementary school students must be increased to support the growth and development of students. To support the growth and development of students, it must be balanced with a balanced nutritional intake (Situmorang, 2015). One of the nutritional problems that are often experienced at this time is malnutrition and excess nutrition, if these problems are not handled immediately it may affect the health of students in the future (Jahri, 2016).

Children who experience the problem of malnutrition in Salasatunaya are caused by low economic factors, lack of food supplies, a poorly educated community environment, and a lack of knowledge about balanced nutrition (Margawati, 2018). Regular diet, genetic influences, and lack of physical activity lead to overweight or obesity. Optimal nutritional status and health are important to maintain so that growth and development can be optimal. In fact, the problem of nutritional status in elementary school students is still relatively high (Rubiyatno, 2014). The intensity and work of muscles requires different energy depending on whether the physical activity is heavy or light. This will also affect your BMI (Body Mass Index). Physical activity and BMI (Body Mass Index) are two interrelated variables because the higher the physical activity, the better the BMI (Body Mass Index) is. Meanwhile, the lower the physical activity that is done, the possibility that the BMI (Body Mass Index) will decrease (Suryana \& Fitri, 2017). Lack of physical activity results in a buildup of energy in the body in the form of fat, this can happen on an ongoing basis and can increase BMI (Body Mass Index). The level of physical activity that is done must be in accordance with the portion, be done regularly, in a structured manner, and not overdo it in order to get good results.

To see the nutritional ${ }^{\mid}$status of children and adölescents áged $15 \Omega 18$ years with BMI (Body Mass Index) with the comparison of WHO / NCHS (World Health Organization / Center for National Health Statistics) (Kemenkes RI, 2010). To see BMI (Body Mass Index) is by Z-score. The person's Z-score division of the reference population's median value divided by the reference population's standard deviation. The Z-score can be calculated in the following way: BMI (Body Mass Index) value measured by Median BMI Value (Body Mass Index) (Kemenkes RI, 2010).

\section{Method}

\section{Type of Research}

This type of research is a quantitative descriptive study, which is a study that meets concrete, objective, measurable, and rational scientific principles. The 
purpose of this study was to describe the physical activity and nutritional status of grade IV-VI students at SDN Bendungan Kec. Pabelan Kab. Semarang.

Time and location of research

When the research was conducted from April 20, 2020 to April 27, 2020, the researchers visited each student's house from $07.00-09.00$. The location of this research was conducted at the homes of students in the village of Bendungan, Kec. Pabelan Kab. Semarang.

\section{Operational definition of research variables}

The operational definition of the variables in this study were physical activity and nutritional status.

\section{Independent Variable}

The independent variable or independent variable in this study, namely physical activity, is an activity that a person does from waking up to sleeping again and routinely a person doing physical activities such as going to school, sleeping, watching TV, sitting, cycling, walking, running, playing football and swimming.

\section{Bound Variables}

The dependent variable or dependent variable is the researcher's concern because this variable is influenced by the independent variable or independent variable. The dependent variable in this study, namely nutritional status, is an assessment of the adequacy of the daily nutritional intake of children as evidenced by measurements of height and weight.

\section{Populationand Research Samplescation. Health and Recreation}

The population in this study were students of class IV-VI SDN Bendungan Kec. Pabelan Kab. Semarang, totaling 60 children. The sampling technique was based on the krejicie and morgan formula with 52 students as respondents, with a confidence level of $95 \%$. The following is a table of the population of class IV-VI students at SDN Bendungan Kec. Pabelan Kab. Semarang.

Table 1. The sample used as research subjects

\begin{tabular}{c|c|c|c}
\hline Class & Male & Women & Total \\
\hline IV & 11 & 8 & 19 \\
\hline V & 9 & 5 & 14 \\
\hline VI & 9 & 10 & 19 \\
\hline Total & 29 & 23 & 52 \\
\hline
\end{tabular}




\section{Research instruments and data collection techniques}

\section{Physical activity}

The physical activity research instrument used the PAQ-C (Physical Activity Questionnaire For Children) questionnaire. This questionnaire aims to determine the level of physical activity during the last 7 days. The validity in the PAQ-C (Physical Activity Questionnaire For Children) instrument validity is between 0.577-0.780. Reliability in the PAQ-C (Physical Activity Questionnaire For Children) instrument proved reliable with a Crombach alpha score of 0.682 .

Physical activity data techniques used the PAQ-C (Physical Activity Questionnaire For Children) questionnaire. With the following procedure:

a. Researchers determine the number of students who will become subjects.

b. Researchers distributed questionnaires to students at their respective homes.

c. Students fill out the PAQ-C questionnaire under the supervision of the researcher.

d. learners collect questionnaires that have been filled.

$$
\text { Mean (average) }=\frac{x 1+x 2+x 3+x \ldots+x n}{n}
$$

Physical activity data is then categorized into the research norm table of the PAQ-C (Physical Activity Questionnaire For Children) questionnaire, the following is a table of research norms:

Table 2.The research norms of the PAQ-C questionnaire (Physical Activity Questionnaires for Children)

\begin{tabular}{c|c|c}
\hline No & Total Value & Category \\
\hline 1 & 1 & Very low \\
\hline 2 journal Phical Edus & 2 cation. Health cLowrecreation \\
\hline 3 & 3 & Moderate \\
\hline 4 & 4 & High \\
\hline 5 & 5 & Very high \\
\hline
\end{tabular}

\section{Nutritional status}

The technique uses anthropometric measurement data by measuring body weight and height, then calculated using an index formula which is then calculated using the BMI (Body Mass Index) formula, which can be done on children, adolescents and adults. To calculate the nutritional status of children and adolescents aged 5-18 years, the value of BMI (Body Mass Index). Then calculate the table based on the weight index according to height in children aged 5-18 years. The formula used to view nutritional status is as follows: 


$$
I M T=\frac{\text { Weight }(\mathrm{kg})}{\text { Height } \times \text { Height }(\mathrm{m})}
$$

\section{Data analysis techniques}

The data analysis technique used is descriptive statistics with percentages. Descriptive statistics, namely having the task of categorizing data and numbers that will provide an orderly, concise and clear picture of a symptom, event, and situation, to support this research, therefore the variables are categorized, namely:

Physical activity variables are categorized and matched in the table with categorization of 1 very low, 2 low, 3 moderate, 4 high, and 5 very high. The second variable is nutritional status (BMI), how to determine it with a limit which is divided into 5 categories, namely very thin, thin, normal, fat, and obese. To find a picture of physical activity, you must calculate the total value in the PAQ-C questionnaire with the following formula:

$\operatorname{Mean}($ rata - rata $)=\frac{x 1+x 2+x 3+x . .+x n}{n}$

Information:

$\mathrm{x}=$ Data to-

$\mathrm{N}=$ number of further data to determine nutritional status categorizing the table below:

Table 3. BMI categories according to the Indonesian Ministry of Health 2020 for children aged 5-

\begin{tabular}{|c|c|c|}
\hline \multirow{5}{*}{$\begin{array}{l}\text { BMI (Body Mass Index) } \\
\text { By Age (BMI / U) } \\
\text { Children aged 5-18 years }\end{array}$} & Threshold Z - skor & Category Nutritional status \\
\hline & cal Ed 3 SD s.d <- 2 SD alth & and Reclnutrition \\
\hline & -2 SD s.d $<1 \mathrm{SD}$ & Good Nutrition (Normal) \\
\hline & $1 \mathrm{SD}$ s.d $<2 \mathrm{SD}$ & More Nutrition \\
\hline & $>2 \mathrm{SD}$ & Obesity \\
\hline
\end{tabular}

To determine the percentage of nutritional status by categorizing with the Zscore brick threshold then analyzing the data using statistical analysis techniques with the following presentation:

$P=\frac{F}{\mathrm{~N}} \times 100 \%$

Information:

$\mathrm{P}=$ Percentage

$\mathrm{F}=$ Frequency

$\mathrm{N}=$ The number of all students

PJKR

https://jurnal.unimed.ac.id/2012/index.php/jpehr 


\section{Result and Discussion}

\section{The term Learners}

Research conducted at SDN Bendungan Kec. Pabelan Kab. Semarang involved 52 students consisting of 29 boys and 23 girls. Respondents in this study were students who were in class IV-VI SDN Bendungan Kec. Pabelan Kab. Semarang. Respondents aged 9-14 years who are included in the transitional period, children to adolescents.

Table 4. criteria for students based on class, gender and age $(\mathrm{N}=52)$

\begin{tabular}{c|c|c}
\hline Variabel & Total & Percentage (\%) \\
\hline Gender & & 56 \\
\hline Male & 29 & 44 \\
\hline Women & 23 & 40 \\
\hline Age & 21 & 56 \\
\hline $11-12$ & 29 & 4 \\
\hline $13-14$ & 2 & \\
\hline
\end{tabular}

\section{Data Sources: Self-processed data}

Based on the table above, it can be seen from the research subjects class IV with the number of respondents $20(38 \%)$, class V 15 (29\%), and class VI 17 students (33\%) with male gender 29 students (56\%)), and women with a total of 23 students (44\%). The criteria for students based on the ages of 9-10 years were 21 students (40\%), $11-12$ years old students $(56 \%)$, and $13-14$ years old students $(4 \%)$.

\section{Physical activity}

The results of the calculation of the physical activity of class IV-VI SDN Bendungan Kec. Pabelan Kab. Semarang, shows the results of the calculation of the physical activity questionnaire PAQ-C are as follows:

Table 5.The results of categorizing physical activity of SDN Bendungan students $(\mathrm{N}=52)$

\begin{tabular}{c|c|c}
\hline Physical activity category & N & Percentage (\%) \\
\hline Very low & 1 & 2 \\
\hline Low & 15 & 29 \\
\hline Moderate & 25 & 48 \\
\hline High & 10 & 19 \\
\hline Very high & 1 & 2 \\
\hline
\end{tabular}

PJKR

https://jurnal.unimed.ac.id/2012/index.php/jpehr 


\begin{tabular}{c|c|c}
\hline Total & 52 & 100 \\
\hline
\end{tabular}

Source: Self-processed data

Based on the table above, it was found that the most results were $25(48 \%)$ of students who did moderate activities out of 52 students, participating in low category physical activity, 15 students with a proportion (29\%), participating in physical activity again with high category 10 students with a proportion (19)\%), very low 1 student with a proportion $(2 \%)$ and a high 1 student with a proportion $(2 \%)$.

\section{Nutritional Status}

The nutritional status of students at SDN Bendungan Kec. Pabelan Kab. Semarang, namely the results of measuring the weight and height of students. The results of measuring nutritional status are as follows:

Table 6. Nutritional status of class IV-VI SDN Bendungan Kec. Pabelan Kab. Semarang (N = 52)

\begin{tabular}{c|c|c|c|c|c|c|c}
\hline \multirow{2}{*}{ No } & Category & \multicolumn{2}{|c|}{ Male } & \multicolumn{2}{c|}{ Female } & \multicolumn{2}{c}{ Total } \\
\cline { 3 - 8 } & & Frekuensi & \% & Frekuensi & \% & Frekuensi & \% \\
\hline 1 & Malnutrition & 11 & 21,2 & 7 & 13,5 & 18 & 34,7 \\
\hline 2 & Normal Nutrition & 17 & 32,7 & 12 & 23,0 & 29 & 55,7 \\
\hline 3 & More Nutrition & 1 & 1,9 & 1 & 1,9 & 2 & 3,8 \\
\hline 4 & Obesity & 0 & 0 & 3 & 5,8 & 3 & 5,8 \\
\hline \multicolumn{2}{r}{ Total } & 29 & 55,6 & 23 & 44,4 & 52 & 100 \\
\hline
\end{tabular}

Data source: Self-processed results

Based on the table above, most of the students had Normal nutritional status of 29 students with a proportion (55.7), followed by a malnutrition status of 18 students with a proportion (34.7), obesity was 3 students with a proportion (5.8), and more nutrition in 2 students with the proportion $(3,8)$.

In this study, normal nutritional status was the highest value for students. Hanur (2019) states that normal nutritional status can occur when the body gets enough nutrients that are used efficiently, so that it supports physical growth, brain development, and work ability reaches optimal levels (Hanur, 2019). Based on the results of the research survey, the low income of parents has a strong influence on the nutritional status of students in grades 4,5 and 6 in SDN Bendungan kec. Pabelan district. Semarang in 2020. Low nutritional knowledge can hinder the improvement of good nutrition, both the family and the community are not only alert, but must understand and are willing to offer nutrition to children (Margawati, 2018). Kuntariningsih (2019) states that the incidence of malnutrition is decreased immunity (easily exposed to disease), experiencing

PJKR

https://jurnal.unimed.ac.id/2012/index.php/jpehr 
disruption in the process of growth and development, lack of energy that can reduce activity at work, and lack of understanding of the importance of nutrient intake for body (Kuntariningsih, 2018).

Students with more nutritional status and obesity usually have habits such as snacks, a lot of solitude, silence, in the room / at home easily tired and sleep more so that they lack activity or even do not like physical activity and exercise. Thonthowi (2019) states that students who experience more nutrition and obesity in addition to their movement skills tend to be stiff and not agile, due to the unbalanced number of calories intake and energy expended, so that more nutrition will even experience obesity (Thonthowi, 2019).

\section{Discussion}

Physical Activity of Students at Bendungan State Elementary School, Kec. Pabelan Kab. Semarang

Physical activity is important for the health of students to carry out daily activities. Physical activity also has an influence on body weight regulation (Situmorang, 2017). Physical activity of students SDN Bendungan Kec. Pabelan Kab. Semarang, the table can be seen that most of the physical activity of students reaches the medium category with a proportion of $48 \%$. This shows that students SDN Bendungan Kec. Pabelan Kab. Semarang in 2020, the description of physical activity is in the moderate category and the nutritional status is in the category of good nutrition (normal).

The results of this study are with Damian's previous research which states that children with low levels of physical activity have a Body Mass Index that is more than normal and are at risk of experiencing nutritional problems or obesity (Damian, 2015). This is because there is no balance between the energy entered in the body and the energy released from the body (Huberty, 2011).

Students who do not do physical activity cause their body to spend less energy. When excessive energy intake is not balanced with physical activity, these students are prone to obesity (Mayangsari, Wahyuningtyas, \& Puspita, 2018). The results of this study were also confirmed by (Budiati, 2013) who explained that the incidence of obesity was influenced by the low level of physical activity carried out by students and the high consumption of macronutrients such as carbohydrates, fats and proteins to produce energy. Conversely, students whose physical activity is in the moderate category will tend to require higher energy so that energy use increases, therefore it has an impact on weight loss (Novitasari, 2016). 
Nutritional Status of Students at the Bendungan State Elementary School, Kec. Pabelan Kab. Semarang

Based on the Indonesian Ministry of Health (2020) regarding anthropometric standards the nutritional status of children and adolescents. The nutritional status of students is determined by their body condition based on BMI / $\mathrm{U}$ which is categorized as under nutrition (underweight), good nutrition (normal), overweight, and obesity (Kemenkes RI, 2020). According to Almatsier (2011) nutritional status is the state of the body as a result of food consumption and use of nutrients. Nutritional status by food consumption and use of nutrients in the body. The results showed that most of the students had good or normal nutritional status, as many as 29 students $(55.7 \%)$, who did sports and recreation regularly. In addition to these results, researchers also found students who experienced obesity. If this is allowed to continue, it can become one of the increasing threats to obesity. This is in line with the results of the Indonesian Ministry of Health (Research and Development Agency for Health Ministry of Health RI, 2013) which states that $10.8 \%$ of the problem of obesity is among those aged 5-12 years. This research is also in line with Octaviani's research (Octaviani, Dody Izhar, \& Amir, 2018), which states that the nutritional status of children aged 47 / IV Elementary Schools in Jambi City has a moderate obesity category (21.7\%).

SDN Bendungan students experienced good or normal nutrition, as many as 29 students $(55.7 \%)$ did sports and recreation regularly. Physical activity is an ideal part of the weight loss program. Physical activities carried out in a proper, regular and measured manner can provide a large enough energy expenditure to maintain a normal (ideal) body weight. In addition, regular exercise can maintain and increase rendurance or physicap fitness and thoid various diseases. Menu, pattern, and portion of the meal, the results of filling out the questionnaire of SDN Bendungan students rarely eat fast food, packaged snacks, packaged drinks, sweet snacks or foods with high fat content. Students consume more vegetables, fruit, milk, and foods that contain lots of fiber, to smooth the digestive system and are good for children's growth and development. Food portions are also appropriate and not excessive (Afrilia, 2018).

Factors that can cause obesity include environmental factors. The school environment also affects students at school. Lack of adequate facilities and infrastructure is also an obstacle for students to be able to carry out physical activities to their full potential. Inadequate field so that there is less space for students to play. The environment outside of school also affects the level of activity after school (at home) in the home environment (Khusnal \& Rahayuningsih, 2010). 
The results showed that students with moderate to high levels of physical activity had a normal body mass index, while students with low levels of physical activity had a body mass index that was more than normal. This proves that the level of physical activity in elementary school students with body mass index with activities that can prevent students from experiencing obesity. Student obesity can occur because of the imbalance between the energy intake released from the body and the energy released from the body, this can be done by diet or physical activity (Novriansyah, 2017).

Energy that cannot occur is not due to eating a lot or excess, but because of physical activity that occurs in excess energy (Amir \& Adi, 2018). Lifestyle in this modern era, this light physical activity will facilitate the incidence of accumulation of fat in the body. The process of the emergence of fat in the body slowly and often not realized. Danari's research shows that there is a relationship that shows between physical activity and the incidence of obesity (Danari, 2013). Obese students are more passive in physical activity so that their physical activity is low. In this study, it mentions students with normal body mass index, with high levels of physical activity. Students who are actively moving have a normal body mass index, so that the energy intake that enters the body is balanced with the energy expended. Physical activity can reduce fat mass in the body and increase strength so that it can prevent excessive fat accumulation in the body (Suryana \& Fitri, 2017).

\section{Conclusion}

Based on the results of the study it can be denied that the students at SDN Bendungan Kec. Pabelan Kab Semarang As many as 25 students (48\%) SDN Bendungan Kec. Pabelan Kab. Semarang is in the moderate physical activity category, 15 students $(29 \%)$ are in the low physical activity category, 10 students $(19 \%)$ are in the high physical activity category, and 2 students $(2 \%)$ are in the very low physical activity category, and 2 peseta students $(2 \%)$ were in the very high physical activity category. A total of 29 students (55.7\%) were categorized as normal nutritional status, 18 students $(34.7 \%)$ were included in the under nutrition category, 3 students $(5.8 \%)$ were categorized as obesity, and 2 students ( $3.8 \%$ ) in the category of over nutrition.

\section{References}

Afrilia, S. (2018). Hubungan pola makan dan aktivitas fisik terhadap status gizi di siswa jurnal gizi, poltekkes kemenkes pontianak, Indonesia. Pontianak Nutrition Journal (PNJ), 1(1), 10-15.

Amir, R. A., \& Adi, A. C. (2018). Gambaran Aktivitas Sedentari Dan Tingkat Kecukupan Gizi Pada Remaja Gizi Lebih Dan Gizi Normal. Media Gizi Indonesia, 12(1), 80. https://doi.org/10.20473/mgi.v12i1.80-87

PJKR

https://jurnal.unimed.ac.id/2012/index.php/jpehr 
Badan Penelitian dan Pengembangan Kesehatan Kemenkes RI. (2013). Riskesdas Biomedis Riset Kesehatan Dasar 2013. 145.

Budiati, A. (2013). Hubungan antara status gizi dan aktivitas fisik dengan angka kesakitan anak di SD Negeri Kartasura 1. Indonesia Jurnal of Primary Education, 1-11, 1-13.

Burhaein, E. (2017). Aktivitas fisik olahraga untuk pertumbuhan dan perkembangan siswa SD. Indonesian Journal of Primary Education, 1(1), 51-58. https://doi.org/10.17509/ijpe.v1i1.7497

Damian. (2015). Hubungan konsumsi fast food dengan obesitas pada remaja di SMP Muhammadiyah $10 \quad$ Yogyakarta. 151, 10-17. https://doi.org/10.1145/3132847.3132886

Danari, A. L. (2013). Hubungan Aktivitas Fisik Dengan Kejadian Obesitas Pada Anak SD di Kota Manado. Jurnal Keperawatan UNSRAT, 1(1), 4-7.

Febrian. (2017). Pengaruh Aktivitas Fisik Yang Berlebihan Terhadap Perubahan Sistem Imun Seluler Spesifik. Jurnal Teori Dan Aplikasi Aktivitas Fisik, 05, (1) $1-6,1-6$.

Hanani, R. (2016). Perbedaan Perkembangan Motorik Kasar, Motorik Halus, Bahasa, Dan Personal Sosial Pada Anak Stunting Dan Non/Stunting. Journal of Nutrition College, 5(4), 412-418. https://doi.org/10.14710/jnc.v5i4.16452

Hanur, S. (2019). Mematik Perkembangan fisik Motorik Anak Usia Dini Melalui Pemberian Gizi Seimbang Dalam Perfektif. 3, 59-72.

Huberty. (2011). Assessing children's physical activity behaviors at recess: A multi-method approach. Pediatric Exercise Science, 23(4), 585-599. https://doi.org/10.1123/pes.23.4.585

Jahri, I. W. S. Y. E. (2016). Gambaran Status Gizi Pada Siswa Sekolah Dasar Kecamatan Rangsang Kabupaten Kepulauan Meranti. Jom Fk, 3(2), 1-12.

Kemenkes RI. (2010). p. 40.

Kemenkes RI. (2017), Profil Kesehatan Indonesia 2016. In Profil Kesehatan Jakarta.

Kemenkes RI, 2020. (2020). Peraturan Mentri Kesehatan Republik Indonesia. (3), 1-78.

Khusnal, E., \& Rahayuningsih, W. S. (2010). Faktor-Faktor Yang Berhubungan Dengan Pola Aktivitas Fisik Pada Anak Kegemukan Usia Sekolah Di Kecamatan Bambanglipuro Bantul Yogyakarta. Sekolah Tinggi Ilmu Kesehatan Aisyiyah Yogyakarta, 1-14.

Kuntariningsih, A. (2018). Analisis Dampak Program Kebun Sekolah untuk Impact Analysis of School Garden Program to Overcome Malnutrition of Children. 4(1), 26-32. Jurnal.

Margawati. (2018). Pengetahuan ibu , pola makan dan status gizi pada anak stunting usia 1-5 tahun di Kelurahan Bangetayu , Kecamatan Genuk , Semarang. Jurnal Pola Makan Dan Status Gizi Pada Anak Stunting, 6(2), 82-89.

Mayangsari, A. R., Wahyuningtyas, W., \& Puspita, I. D. (2018). Hubungan Aktivitas Fisik, Durasi Tidur, Kebiasaan Sarapan dan Konsumsi Fast Food

PJKR

https://jurnal.unimed.ac.id/2012/index.php/jpehr 
dengan Kejadian Overweight pada Anak Sekolah Dasar. Nutri Sains, 2(2), $11-18$.

Novitasari, D. (2016). Tingkat Konsumsi Energi, Aktivitas Fisik Dan Kesegaran Jasmani Pada Posisi (Tosser Dan Smasher) Atlet Bola Voli. Jurnal Kesehatan Masyarakat (e-Journal), 4(2), 38-45.

Novriansyah, A. (2017). Gambaran Perilaku Aktivitas Fisik Dan Kebiasaan Makan Pada Siswa/Siswi Smk Muhammadiyah 5 Jakarta. Jurnal.

Octaviani, P., Dody Izhar, M., \& Amir, A. (2018). Hubungan pola makan dan aktivitas fisikengan status gizi pada anak sekolah dasar di SD Negeri 47/IV kota Jambi. Jurnal Kesmas Jambi, 2(2), 56-66.

Rubiyatno, R. (2014). Peranan aktivitas olahraga bagi tumbuh kembang anak. Jurnal Pendidikan Olahraga, 3(88), 54-64.

Situmorang, M. (2015). Penentuan Indeks Massa Tubuh (IMT) melalui Pengukuran Berat dan Tinggi Badan Berbasis MikrokontrolerAT89S51 dan PC. Jurnal Teori Dan Aplikasi Fisika, 03(02), 102-110.

Situmorang, M. (2017). Hubungan pola makan dan aktivitas fisik dengan kejadian obesitas mahasiswa Politeknik Kesehatan Kemenkes Aceh. AcTion: Aceh Nutrition Journ, 2(1), 1-5. https://doi.org/10.30867/action.v2i1.29

Sofingi, I. (2018). Pengaruh pelatihan terhadap pengetahuantentang gizi buruk dan inter-profesional collaboration. Jurnal Gizi Indonesia, 11(1), 61-71.

Suryana, S., \& Fitri, Y. (2017). Hubungan Aktivitas Fisik dengan IMT dan Komposisi Lemak Tubuh. AcTion: Aceh Nutrition Journal, 2(2), 114. https://doi.org/10.30867/action.v2i2.64

Thonthowi. (2019). Asupan protein dan kalsium serta aktivitas fisik pada anak usia sekolah dasar Protein and calcium intake and physical activity in school-aged children. 02(02), 79-88. Jurnal.

Winarsi. (2016). Stress oksidatif dan status antioksidan pada aktivitas fisik maksimal. Ph Generasi Kampus, and 9(2), reation 176-189. https://doi.org/10.1042/BJ20091286 